\title{
Application of Small Group Discussion (SGD), Collaborative Learning (CbL) and Problem Based Learning (PBL) as Learning Methods and Student Assessment Strategies in Engineering Drawing Courses
}

\author{
Taufiq Ihsan ${ }^{1}$, Tivany Edwin ${ }^{2}$ \\ \{taufiqihsan@eng.unand.ac.id ${ }^{1}$, tivani.edwin2@gmail.com² ${ }^{2}$ \\ ${ }^{1,2}$ Environmental Engineering Department, Faculty of Engineering, Universitas Andalas, Padang, \\ Indonesia
}

\begin{abstract}
Implementation of learning Engineering Drawing courses based on Student Center Learning application with several methods such as, Small Group Discussion (SGD), Collaborative Learning (CbL) dan Problem Based Learning (PBL). The purpose of the SCL method was developed soft skill competencies of students in an effort to achieve the expected. Application of this method was in the even semester for 116 of 6 th grade students in 2018/2019. Assessment is done with the purpose of learning student performance assessment through assessment of written tests, tasks, papers, presentations and demonstrations as well as the attitudes of students. Results of the questionnaire on the SCL method implementation shows that most perceptions expressed by students is positive $(87.45 \%)$ though some students argue the opposite perception $(12.55 \%)$. Required evaluation and further development of the SCL method application related to the method of learning approach designed.
\end{abstract}

Keywords: Student Center Learning, Engineering Drawing, Small Group Discussion (SGD), Collaborative Learning (CbL) dan Problem Based Learning (PBL)..

\section{Introduction}

The Engineering Drawing course was part of the Compulsory Subjects group in the Environmental Engineering Department of Universitas Andalas, and all students needed to take it with a weight of 3 credits. Lecture materials prepared based on the needs of students, relating to the buildings about applications in the field of environmental engineering, that was needed in the world of work, especially in the field of engineering at this time. This course discusses the rules of engineering drawing, projection drawings, images of simple buildings, piping and valves, depictions of pipelines and applications for drawing in the field of environmental engineering. There are two learning objectives for this course. Firstly, students were able to draw pictures related to simple buildings in the area of Environmental Engineering. Secondly, students can think critically, collaborate, active, creative and 
communicative, analytical skills, logical arguments, solve problems, can summarize, listen and manage time (soft skills).

During this time, engineering drawing lectures were mostly carried out with the TCL system (Teacher Center Learning). Teaching materials in the form of power points developed by the teaching team of the subject, which was supplemented by the provision of assignments. Students obtained in the previous semester (even semester 2017/2018) for three different classes (classes A, B, and C) was as many as $4.45 \%$ failed in this course. As the main subject for first-year students, and it means that the material in this course was primary, students should have more ability to get the best grades in this course. Besides, when there was a competency test (final assignment/thesis), some questions related to this course cannot be answered by students. This condition showed that the lecture process had not gone well.

The effectiveness of this method in achieving the desired learning competencies (both hard skills and soft skills) [1,2] encourages the application of the SCL method in learning Engineering Drawing courses. It is expected to motivate students to become active learners and support achievement competence (aspects of general and unique workability; general and particular aspects of mastery of knowledge/science; and aspects of managerial ability that are by the scope of authority and responsibility).

\section{Methodology}

The SCL method developed in the Drawing Engineering course, that was a combination of Small Group Discussion (SGD), Collaborative Learning (CbL), and Problem Based Learning (PBL). This method emphasized more student-centered activities (demanding student activity) and cooperation. In this activity, the lecturer moves as a facilitator and dynamic (balancer) in a discussion activity. The lecturer prepares the material for student discussion. 116 students explore and resolve existing problems and continue with class discussions (presentation) of each small group. So that student was tasked with finding as much information as possible on the given topic. This condition explores student creativity. Furthermore, this system supported efforts to realize the expected profile of graduates.

The implementation of activities in the classroom was as follows:

1. At the first meeting, the lecturer delivered the Semester Learning Plan and also included materials and learning systems.

2. Students divided into small groups, each group consisting of 5 people.

3. The lecturer prepares several case studies related to the material in the Engineering Drawing course.

4. Students discuss with group members all matters relating to the content provided. Besides, students were also asked to look for other materials related to the material

5. Students make discussion results in the form of powerpoints (present the results of group work to explain the content discussed), then discuss in class (with other group members)

6. Lecturers monitor the learning process and outcome of student learning and provided an assessment of student activity.

The implementation of extensive practicum/task activities is as follows: 
1. Students got practicum dictates (that compiled by team teaching) then the lecturers together with assistants will provide explanations to students about implementing large task objects (assistance).

2. The division of students into small groups, each group has a maximum of 8 people

3. The lecturer monitored the execution of large tasks every week and accompanied by an assistant

4. Students worked on and solved each problem set and make a report in the form of technical drawings that have been done in the specified image area.

5. Students created a set of masters in the way of powerpoints (present the results of group work to provide explanations), then discuss them in class (with other group members).

6. Lecturers monitored the learning process and student learning outcomes and provide an assessment of student activity.

Assessment of soft skills competencies through the perception scale rubric to assess the performance of individual discussions/presentations in small groups with the following assessment conditions [3]:

Table 1. Perception Scale Rubric

\begin{tabular}{|c|c|c|c|c|c|c|}
\hline \multirow{2}{*}{ No. } & \multirow{2}{*}{ Rated Aspect } & \multicolumn{5}{|c|}{ Scale } \\
\hline & & 1 & 2 & 3 & 4 & 5 \\
\hline \multirow[t]{5}{*}{1} & Effective Communication & & & & & \\
\hline & Motivating word selection & & & & & \\
\hline & Ways and expressions in the presentation & & & & & \\
\hline & Mastery of presentation media & & & & & \\
\hline & Allow discussing with listeners & & & & & \\
\hline \multirow[t]{4}{*}{2} & Teamwork & & & & & \\
\hline & Activeness in collaboration in groups & & & & & \\
\hline & Contribution of collaboration in groups & & & & & \\
\hline & Leadership & & & & & \\
\hline \multirow[t]{3}{*}{3} & Processing Information & & & & & \\
\hline & Extracting & & & & & \\
\hline & Interpreting & & & & & \\
\hline \multirow[t]{4}{*}{4} & Thinking Ways & & & & & \\
\hline & Mastery & & & & & \\
\hline & Smart ideas/ thoughts/explanations & & & & & \\
\hline & Papers performance & & & & & \\
\hline & $\begin{array}{l}=0-40 \quad: \text { Very Bad } \\
=41-55: \text { Poor } \\
=56-65: \text { Fair } \\
=66-80: \text { Good } \\
=81-100: \text { Excellent }\end{array}$ & & & & & \\
\hline
\end{tabular}

The assessment report used descriptive rubrics to assess the performance of group reports as follows [3]: 
Table 2. Descriptive Rubric

\begin{tabular}{lll}
\hline No. & Rated Aspect & Grade \\
\hline 1. & Systematic report & \\
2. & Complete report & \\
3. & Clarity and coherence & \\
4. & References & \\
5. & Business students in compiling reports (soft skill) & \\
6. & Frequency of report assistance (soft skill) & \\
\hline
\end{tabular}

The criteria for evaluating group reports are as follows:

1. Systematics report

$1=$ wrong systematics

$2=$ systematics are incorrect and unclear

$3=$ correct systematics but is not clear

$4=$ following the correct and clear systematics

2. Complete report

$1=$ incomplete

2 = without any chapter discussion, conclusions, and bibliography

$3=$ without conclusions

$4=$ full report following the instructions for making a report

3. Report clarity and clamor

$1=$ unclear, not by the demands of writing

$2=$ the report is not following the writing demands

$3=$ clear report but not following the writing demands

$4=$ report is clear and following the demands of report writing

4. Reference renewal

$1=\geq 20$ years

$2=15-<20$ years

$3=10-<15$ years

$4=\leq 10$ years

5. Business students in compiling reports

$1=$ does not attempt to complete and correct the report

$2=$ trying to improve the report, but there are two aspects not corrected

$3=$ trying to improve the report, but there is one incomplete aspect

$4=$ try to correct the report seriously and complete report arrangement

At the end of the lecture, student polls were conducted using the questionnaire method. The results of the questionnaire to assess the performance of the SCL method in developing soft skills.

\section{Results and Discussion}

The beginning of the class, there was a contract agreement and a discussion of student expectations for this course. Besides, at the first meeting, a class coordinator was selected, and the formation of a large independent discussion/task group (with members of 5-8 students) based on diversity of backgrounds, sexes, and abilities.

The results of the class showed that the application of SCL in the Engineering Drawing Course could run well. This result indicated by the value of the assignment given and the final value of the student. The questionnaire results of the students 'perceptions at the end of the 
lecture stating that the application of the SCL method had a positive impact on students' soft skills $(87.45 \%)$ compared to those with a negative perception (12.55\%). This questionnaire includes several perception questions as follows [4]:

a. The development of the ability to analyze cases/problems

b. Increased ability to write scientifically

c. Group presentations and discussions are more interesting

d. Interactive discussions make the learning process more interesting

e. Discuss and engage in problem-solving

f. Optimizing one's abilities

g. Increase active learning interest both individually and in groups

h. More enthusiastic and more understanding of the material given (because preparing from home)

i. Train public speaking and be responsible

The results of the questionnaire can be seen in Table 4. Distribution of assignment values and final grades of students can be seen in Figures 1 and 2.

Table 4. Questionnaire results of students participating in Engineering Drawing courses

\begin{tabular}{|c|c|c|}
\hline 1 & Development of Ability to Analyze cases/problems & 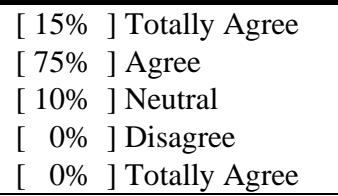 \\
\hline 2 & Increased Scientific Writing Ability & $\begin{array}{l}\text { [ } 10 \% \text { ] Totally Agree } \\
{[73.7 \%] \text { Agree }} \\
{[26.3 \% \text { ] Neutral }} \\
{\left[\begin{array}{c}0 \% \\
{[0 \% \text { Disagree }}\end{array}\right.} \\
{[0 \% \text { Totally Disagree }}\end{array}$ \\
\hline 3 & Presentations and Group Discussions are more interesting & 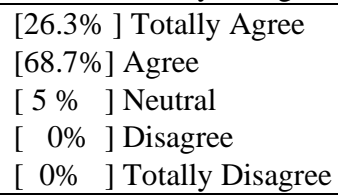 \\
\hline 4 & $\begin{array}{l}\text { The interactive discussion makes the learning process more } \\
\text { interesting }\end{array}$ & 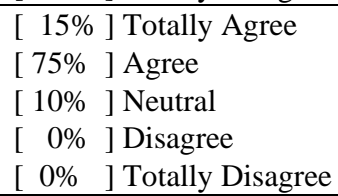 \\
\hline 5 & Discuss and engage in problem-solving & 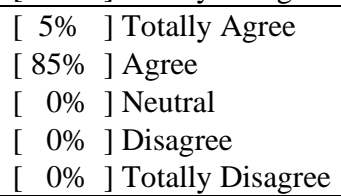 \\
\hline 6 & Optimizing Self Ability & $\begin{array}{l}\text { [ } 10 \% \text { ] Totally Agree } \\
{[85 \% \text { ] Agree }} \\
{[5 \% \text { ] Neutral }} \\
{\left[\begin{array}{c}0 \% \\
{[}\end{array} \text { Disagree }\right.} \\
{[0 \% \text { ] Totally Agree }}\end{array}$ \\
\hline
\end{tabular}




\begin{tabular}{lll}
\hline 7 Increasing Interest in Active Learning both individually and & {$[15 \%]$ Totally Agree } \\
in groups & {$[75 \%]$ Agree } \\
& {$[10 \%]$ Neutral } \\
& {$[0 \%$ Disagree } \\
& {$[0 \%$ ] Totally Disagree } \\
\hline More enthusiastic and more understanding of the & {$[0 \%]$ Totally Agree } \\
material given because preparing from home & {$[84.3 \%]$ Agree } \\
& {$[15.7 \%]$ Neutral } \\
& {$[0 \%]$ Disagree } \\
& {$[0 \%]$ Totally Disagree } \\
\hline Train public speaking and be responsible & {$[26.3 \%]$ Totally Agree } \\
& {$[74.7 \%]$ Agree } \\
& {$[0 \%]$ Neutral } \\
& {$[0 \%]$ Disagree } \\
& {$[0 \%]$ Totally disagree } \\
\hline
\end{tabular}

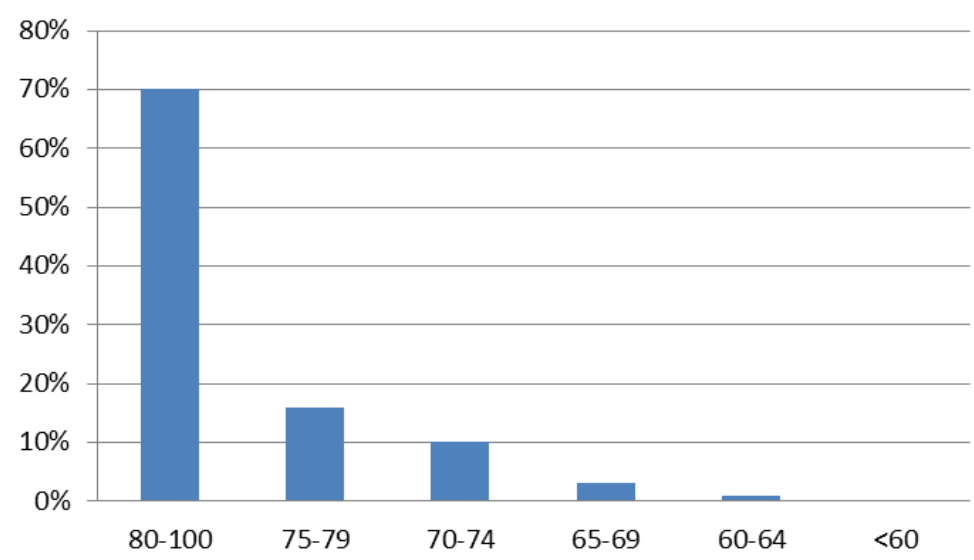

Fig 1. Distribution of Value Assignment Percentages during Engineering Drawing Lectures

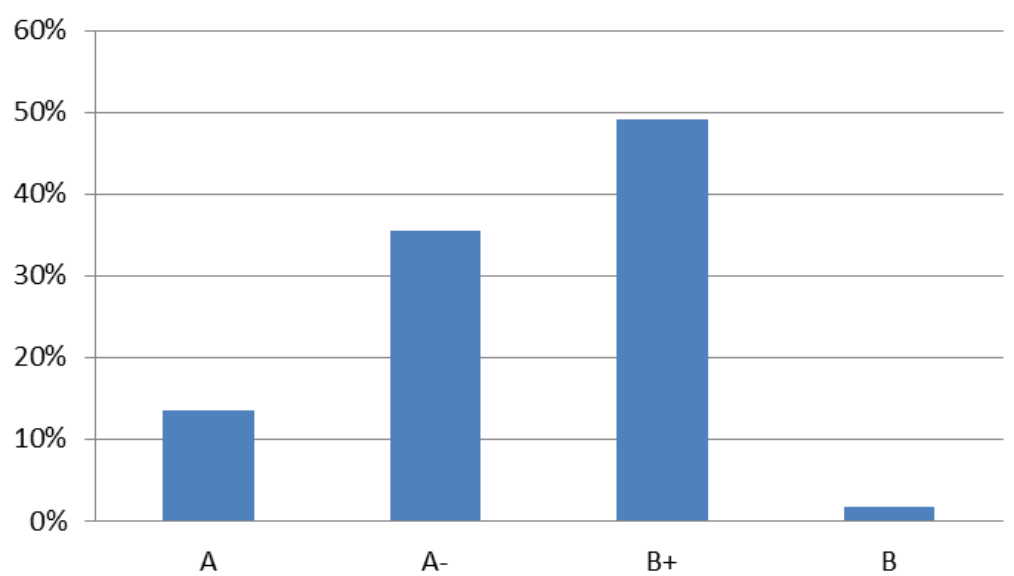

Fig 2. Distribution of Student Final Value Percentage 
The application of the SCL method with Small Group Discussion (SGD); Collaborative Learning (CbL); and Problem Based Learning (PBL); in engineering drawing courses (even semester 2018/2019), had a positive effect on the development of soft skills. Furthermore, it was necessary to evaluate the learning methods, so that the expected competencies (both hard skills and soft skills) can be achieved better.

\section{Acknowledgments}

The authors are grateful to the Lembaga Pengembangan Pendidikan dan Penjaminan Mutu (Educational Development and Quality Assurance Institution) Universitas Andalas that granted research fund for this study under contract No. 049/UN.16.18/PT.01.03/2019.

\section{References}

[1] Gulo,W. Strategi Belajar Mengajar. Jakarta: Grasindo (2002).

[2] Kurdi, Fauziah, N. Penerapan student-centered learning dari teacher-centered learning mata ajar ilmu kesehatan pada program studi penjakes.Forum Kependidikan, Vol.28, No. 2 (2009).

[3] Arifin, S.Assessment \& evaluasi dalam pembelajaran SCL.Materi sosialisasi DIKTI. ITS (2015)

[4] Hadi, R. Dari Teacher-Centered Learning ke Student-Centereded Learning: Perubahan Metode Pembelajaran di Perguruan Tinggi. Insania, Vol.12, No. 3. hal. 408-419 (2007) 